\title{
Pattern of pediatric dermatoses at a tertiary care hospital, SIMS, Shivamogga
}

\author{
Dadapeer. H.J ${ }^{1}$, Anupama. Y.G ${ }^{2, *}$, Sushma. D.M³, Aishwarya. A.C ${ }^{4}$ \\ ${ }^{1}$ Professor and HOD, ${ }^{2}$ Assistant Professor, ${ }^{3}$ Senior Resident, ${ }^{4}$ Junior Resident, Dept. of Dermatology, Shimoga Institute of \\ Medical Sciences, Shimoga, Karnataka, India
}

\section{*Corresponding Author:}

Email: dranu82@yahoo.co.in

\begin{abstract}
Introduction: The major health problem in the pediatric age group is skin diseases and is associated with the significant morbidity.

Aim: To study the incidence of dermatoses among the pediatric age group at tertiary health care in Shivamogga.

Materials and Methods: A prospective study was carried out among the children upto 14 years who came to Dermatology outpatient department. The study was carried out between the month of January to March 2018. Diagnosis was made based on appropriated detailed history, cinical features and investigations.

Results: The commonest pediatric dermatoses in our study were the infections and infestations. This was followed by other noninfective dermatoses like insect bite reactions, miliaria, dermatitis and others.

Conclusion: Infections are the dermatoses which exceeded in our study and these are potentially controllable and preventable. Hence health care strategies that target infections represent the key to an efficient child health care program.
\end{abstract}

Keywords: Children, Dermatoses, Infections.

\section{Introduction}

Skin diseases are a major health problem in the pediatric age group and are associated with significant morbidity. $30 \%$ constitute the childhood skin disesases among the visit to pediatrician as well as to the dermatoogists. ${ }^{1,2}$ The predisposing factors of dermatoses in children are socioeconomic status, climatic exposure, dietary habits and external environment as compared to adults. Hence we undertook this study to determine the pattern of common dermatoses in children as there are few studies on the spectrum of pediatric dermatoses from Shivamogga.

\section{Materials and Methods}

A prospective study was conducted in Dermatology outpatient department, District Mc Gann Teaching Hospital, SIMS, Shivamogga during January to March 2018. All children aged from 1 to 14 years with dermatoses were enrolled in the study. Patients were diagnosed by appropriate history, clinical examination and investigations. Results were tabulated based on the etiology and were analyzed.

\section{Results}

During the study period, total number of patients seen in dermatology outpatient department was 7211. Out of these, 972 were of paediatric age group. There were 600 boys and 372 girls, with male to female ratio of 1.6: 1 . The age and sex distribution is given in table 1. Most common type of pediatric dermatoses found in our study were infections and infestations constituting $56.4 \%$, followed by insect bite reaction $(10.4 \%)$ as shown in the Table 2. The pattern of various infections and infestations are depicted in the Table 3. Impetigo
(20.5\%) was the most common bacterial infection and scabies (13.6\%) was the commonest infestation (Fig. 2). Tinea capitis and corporis (8.1\%) and molloscum contagiosum $(7.1 \%)$ were the commonest fungal and viral infections respectively.

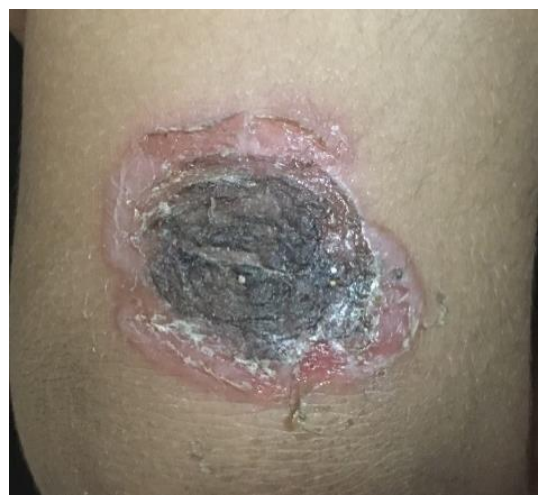

Fig. 1: Impetigo

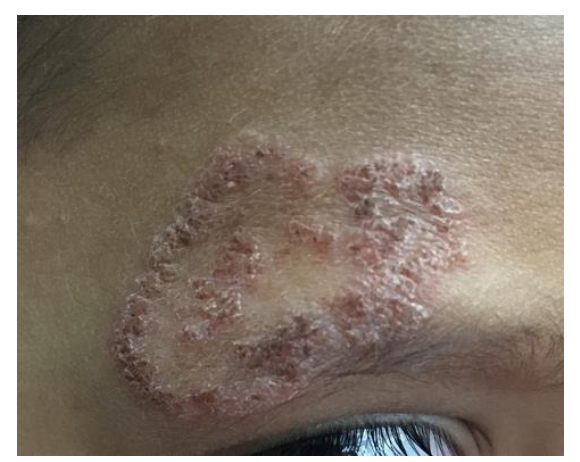

Fig. 2: Tinea 


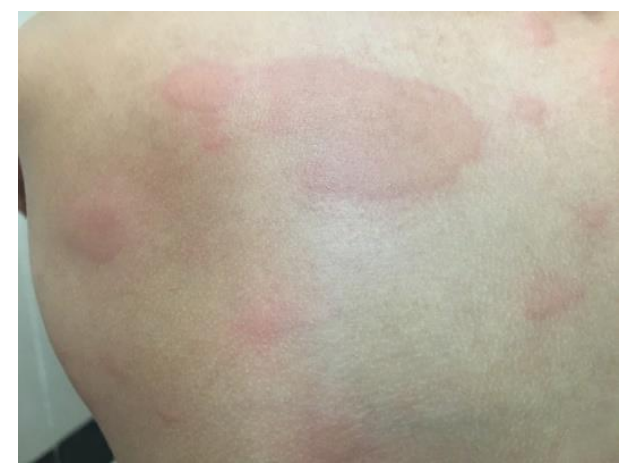

Fig. 3: Urticaria

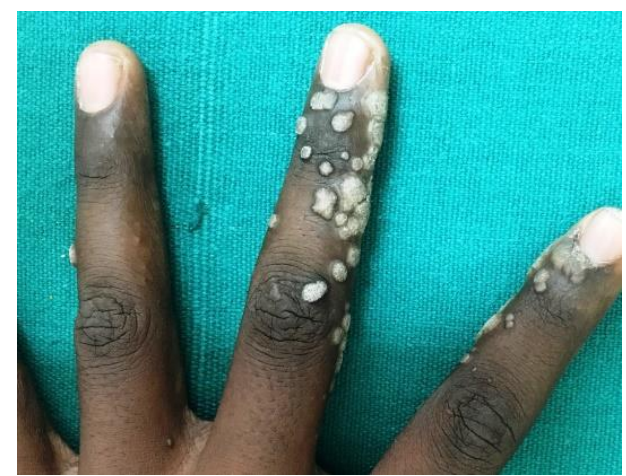

Fig. 4: Wart

\section{Discussion}

Atopic dermatitis is the most common dermatoses in developed countries but in developing countries it is infections that predominate. $56.4 \%$ of dermatoses constituted infections in our study. Karthikeyan $\mathrm{K}$ et al showed that infections and infestations $(54.5 \%)$ were the most common pediatric dermatoses (3). Most of the studies reported that the incidence of infections and infestations to be high ranging from $63.5 \%-85.2 \% .^{4-7}$ These can be attributed to poor hygienic, overcrowding and low socioeconomic status.

Among infections, first comes pyoderma (40.9\%) and then viral $(25.6 \%)$ and fungal infections $(13.1 \%)$. In a study conducted by Karthikeyan $\mathrm{K}$ et al, ${ }^{3}$ pyoderma was the most common infectious disorder in the children similar to our study. Out of bacterial infections, impetigo $(20.5 \%)$ was the common entity followed by secondary pyoderma $(9.4 \%)$ which is not in accordance with study by Nageswaramma et al in which secondary pyoderma was most common compared to impetigo.
Among viral infections, molluscum contagiosum (7.1\%) was most common, followed by viral warts (5.4\%); similar to findings observed by the study of Sharma and Mendiratta. ${ }^{9}$ While study by Patel et al (10), the higher incidence of warts in children were found high compared to molluscum contagiosum.

In our study $13.1 \%$ constituted the fungal infections. Tinea capitis (4.49\%) was the most common fungal infection similar with finding of other studies. ${ }^{11,12}$

In infestations, scabies accounted for $13.6 \%$ followed by pediculosis capitis $(6.5 \%)$. The incidence of scabies has varied in various studies from $5.1 \%$ $22.4 \% .^{4-7,13}$ Higher percentage of scabies can be attributed to poor hygiene, overcrowding and low socio-economic strata. The incidence of pediculosis capitis was low (6.5\%) compared to other studies in India. ${ }^{14,15}$ The decreased incidence in our study could be due to increased awareness on hair care and hygiene.

Following infections and infestations, the next large group is papular urticaria (insect bite reaction). The incidence is similar to a study conducted in Andhra Pradesh. ${ }^{8}$

Miliaria cases were high in the study might be due to seasonal variation, more prevalent in summer and rainy seasons which is in accordance with a study by Banerjee et al. ${ }^{16}$

Dermatitis and eczema constituted $6.4 \%$ whereas in developed countries studies showed higher incidence of eczema from $18 \%$ to $34 \% .{ }^{17-21}$ Lower incidence of atopic dermatitis and eczema in our study may be related to climate, dietary habits, genetics, or other unknown factors.

Psoriasis accounted for $1.2 \%$ in this study which is in accordance with Rao et $\mathrm{al}^{22}$ Jawade et $\mathrm{al}^{23}$ and Sardana $\mathrm{K}^{24}$ studies. Incidence of pigmentary disorders in our study was found to be $2.7 \%$ similar to studies by Thappa $(3.16 \%)^{1}$ and Nageswaramma $(2.81 \%),{ }^{8}$ while higher incidence was found in Patel et al. (11.48\%) study ${ }^{25}$ Nutritional disorders were found in about $2.1 \%$ of children, which was in accordance with a study by Sugat Jawade et al. ${ }^{23}$ However, a study by Negi et al, ${ }^{4}$ incidence is very high compared to our study. Negi et $\mathrm{al}^{4}$ study was done in a rural area while our study center was in an urban area. Incidence of hair and nail disorders was $1.5 \%$, finding similar to the study by Sugat Jawade et al. ${ }^{23}$ Urticaria affects about 3\% of study population which correlates with other study. ${ }^{1}$

Table 1: Age and sex distribution

\begin{tabular}{|l|c|c|l|}
\hline Age in yrs & Male & Female & Total \\
\hline $1-4$ & $9(9.4 \%)$ & $60(6.1 \%)$ & $152(15.6 \%)$ \\
\hline $5-8$ & $188(19.8 \%)$ & $96(9.8 \%)$ & $284(29.2 \%)$ \\
\hline $9-12$ & $320(32.9 \%)$ & $216(22.2 \%)$ & $536(55.1 \%)$ \\
\hline Total & $600(61.7 \%)$ & $372(38.2 \%)$ & $972(100 \%)$ \\
\hline
\end{tabular}


Table 2: Pattern of pediatric dermatoses

\begin{tabular}{|l|c|c|}
\hline Dermatoses & No. of patients & Percentage \\
\hline Infections and infestations & 549 & 56.4 \\
\hline Dermatitis and eczema & 63 & 6.4 \\
\hline Pigmentary disorders & 27 & 2.7 \\
\hline Insect bite reaction & 102 & 10.4 \\
\hline Disorders of hair and nails & 15 & 1.5 \\
\hline Miliaria & 69 & 7 \\
\hline Nutritional deficiency disorder & 21 & 2.1 \\
\hline Urticaria & 30 & 3 \\
\hline Genetic disorders & 6 & .6 \\
\hline Acne & 30 & 3 \\
\hline Collagen vascular disorders & - & - \\
\hline Haemangioma & 6 & .6 \\
\hline Drug eruptions & 6 & .6 \\
\hline Psoriasis & 12 & 1.2 \\
\hline Others & 36 & 3.7 \\
\hline Total & 972 & 100 \\
\hline
\end{tabular}

Table 3: Pattern of infections and infestations

\begin{tabular}{|l|c|c|}
\hline Dermatoses & No. of cases & Percentage \\
\hline Pyoderma & 225 & 40.9 \\
Secondary pyoderma & 52 & 9.4 \\
Impetigo & 113 & 20.5 \\
Bullous impetigo & 60 & 10.9 \\
\hline Infestations & 111 & 20.2 \\
Scabies & 75 & 13.6 \\
Pediculosis & 36 & 6.5 \\
\hline Fungal infections & 72 & 13.1 \\
Tinea corporis and capitis & 45 & 8.1 \\
Tinea versicolor & 18 & 3.2 \\
Candidiasis & 09 & 1.6 \\
\hline Viral infections & 141 & 25.6 \\
Molluscum contagiosum & 39 & 7.1 \\
Warts & 30 & 5.4 \\
Herpes simplex & 9 & 1.6 \\
Varicella zoster & 33 & 6 \\
Viral exanthems & 30 & 5.4 \\
\hline
\end{tabular}

\section{Conclusion}

Infections outnumbered other pediatric dermatoses in our study. These are potentially controllable and preventable easily by public awareness, proper sanitation and providing health care facilities. Hence we could like to highlight the fact that health care strategies that target infections represent the key to an efficient child health care program.

\section{References}

1. Thappa DM. Common skin problems in children. Indian J Pediatr. 2002;69:701-706.

2. Federman DG, Reid MC, Feldman SR, Greenhoe J, Kirsner RS. The primary care provider and the care of skin disease. Arch Dermatol. 2001;137:25-29.

3. Karthikeyan K, Thappa DM, Jeevankumar B. Pattern of pediatric dermatoses in a referral centre in South India. Indian Pediatr. 2004;41:373-7.
4. Negi KS, Kandpal SD, Prasad D. Pattern of skin diseases in children in Garhwal region of Uttar Pradesh. Indian Pediatr. 2001;38:77-80.

5. Sharma RC, Mendiratta RC. Clinical profile of cutaneous infections and infestations in pediatric age group. Indian J Dermatol. 1999;44:174-178.

6. Bhatia V. Extent and pattern of pediatric dermatoses in central India. Indian J Dermatol Venereol Leprol. 1997;63:22-25.

7. Ghosh SK, Saha DK, Roy AK. A clinico aetiological study of dermatoses in pediatric age group. Indian $J$ Dermatol.1995;40:29-31.

8. S. Nageswaramma, G. Swarna Kumari, T. V.Narasimha Rao,et al. Skin Disoders of Childhood. IOSR Journal of Dental and Medical Sciences. 2015;14:07-12.

9. Sharma RC, Mendiratta V. Clinical profile of cutaneous infections and infestations in paediatric age group. Indian J Dermatol. 1999;44:174-8.

10. Patel JK, Vyas AP, Berman B, Vierra M. Incidence of childhood dermatoses in India. Skinmed. 2010;8:136-42. 
11. Survey of clinical paediatrics. 6th ed. London: Mcgraw Hill Kogakusha Ltd; 1974. Wasserman Edward and Slobody Lawrence.

12. Wisuthsarewong W, Viravan S. Analysis of skin diseases in a referral pediatric dermatology clinic in Thailand. $J$ Med Assoc Thai. 2000;83:999-1004.

13. Porter MJ, Mack RW, Chaudhary MA. Pediatric skin disease in Pakistan. A Study of three Punjab villages. Int J Dermatol. 1984;23:613-617.

14. Sharma NL, Sharma RC. Prevalence of dermatologic diseases in school children of a high altitude tribal area of Himachal Pradesh. Indian J Dermatol Venereol Lepro1. 1990;56:375-376.

15. Kumar V, Garg BR, Baruah MC. Prevalence of dermatological diseases in school children in a semi urban area in Pondicherry. Indian Dermatol Venereol Leprol. 1988;54:300-302.

16. Banerjee S, Gangopadhyay DN, Jana S, Mitra C. Seasonal variations in pediatric dermatoses. Indian $J$ Dermatol. 2010;55:44-6.

17. Prevalence, morbidity, and cost of dermatological diseases. J Invest Dermatol. 1979;73:395-401.

18. Bowker NC, Cross KW, Fairburn EA, Wall M. Sociological implications of an epidemiological study of eczema in the city of Birmingham. $\mathrm{Br} J$ Dermatol. 1976:95:137-44.
19. Horn R. The pattern of skin diseases in general practice. Dermatol Pract. 1986;2:14-9.

20. Katelaris CH, Peake JE. Allergy and the skin: Eczema and chronic urticaria. Med J Aust. 2006;185:517-22.

21. Chiang LC, Chen YH, Hsueh KC, Huang JL. Prevalence and severity of symptoms of asthma, allergic rhinitis, and eczema in 10- to 15 year old schoolchildren in central Taiwan. Asian Pac J Allergy Immunol. 2007;25:1-5.

22. Rao GS, Kumar SS, Sandhya Pattern of skin diseases in an Indian village. Indian J Med Sci. 2003;57:108-10.

23. Jawade SA, Chugh VS, Gohil SK, Mistry AS, Umrigar DD. A clinico-etiological study of dermatoses in pediatric age group in tertiary health care center in South Gujarat region. Indian J Dermatol. 2015;60:635.

24. Sardana K, Mahajan S, Sarkar R, Mendiratta V, Bhushan $\mathrm{P}$, Koranne RV, et al. Spetrum of Skin Disease among Indian Children. Pediatr Dermatol. 2009;26:6-13.

25. Patel JK, Vyas AP, Berman B, Vierra M. Incidence of childhood dermatoses in India. Skinmed. 2010;8:136-42.

How to cite this article: Dadapeer HJ, Anupama YG, Sushma DM, Aishwarya AC. Pattern of pediatric dermatoses at a tertiary care hospital, SIMS, Shivamogga. Ind J Clin Exp Dermatol. 2018;4(3):201-204. 